\title{
Record of aquatic invertebrates associated with the bromeliads Aechmea ornata (Baker) and Aechmea recurvata (Klotzsch) L. B. Sm in two Atlantic Rainforest fragments of south Brazil
}

Registro de invertebrados aquáticos associados às bromélias Aechmea ornata (Baker) e Aechmea recurvata (Klotzsch) L. B. Sm em dois fragmentos de Mata Atlântica do sul do Brasil

Yuri Kataoka Silva ${ }^{1}$ (D), Anderson de Souza Moser $^{2}$ (D), Mônica Ceneviva-Bastos ${ }^{1}$ (D) and

\section{Ana Lucia Suriani Affonso ${ }^{1 *}$ (i)}

${ }^{1}$ Universidade Estadual do Centro-Oeste - Unicentro, Alameda Élio Antonio Dalla Vecchia, 838, CEP 85040-167, Guarapuava, PR, Brasil

${ }^{2}$ Universidade Federal do Paraná - UFPR, Rua XV de Novembro, 1299, CEP 80060-000, Curitiba, PR, Brasil

*e-mail: analuciabio@gmail.com

Cite as: Silva, Y.K. et al. Record of aquatic invertebrates associated with the bromeliads Aechmea ornata (Baker) and Aechmea recurvata (Klotzsch) L. B. Sm in two Atlantic Rainforest fragments of south Brazil. Acta Limnologica Brasiliensia, 2021, vol. 33, e25.

Abstract: Bromeliads are numerous both in diversity and abundance in the Atlantic Rainforest, one of the most threatened biomes on Earth. They are also an important habitat for several animal species that live in the water retained by its rosette structure. In this study, we aimed to characterize and compare the macroinvertebrate community of two bromeliad species from Atlantic forest fragments. One is characteristic of Dense Ombrophilous Forests, Aechmea ornata, and the other occurs in Mixed Ombrophilous Forests, Aechmea recurvata. We sampled and identified macroinvertebrates form 24 bromeliads, 12 of each species. A total of 19 taxa and 656 specimens were sampled. In both bromeliad species, Diptera was the most abundant insect order $(n=417)$, represented mostly by mosquitoes $(n=227)$ and non-biting midges $(n=107)$, followed by Scirtidae marsh beetles $(n=216)$. Aechmea ornata presented higher abundance and lower invertebrate richness compared to Aechmea recurvata. Seven taxa were exclusive of $A$. recurvata, eight were common to both, and four, including a sponge, occurred only in $A$. ornata. The most abundant invertebrate taxa were common to both bromeliads and are regarded as typical of lentic environments. On the other hand, the high number of exclusive species indicates that conservation efforts should include bromeliads from these two phytophysiognomies to secure protecting the diversity of phytotelmata communities.

Keywords: phytotelmata; aquatic insects; Ombrophilous Forests; diversity.

Resumo: As bromélias são numerosas em diversidade e abundância na Mata Atlântica, um dos biomas mais ameaçados do planeta. Elas também são um habitat importante para várias espécies de animais que vivem na água retida por sua estrutura em roseta. Neste estudo, objetivamos caracterizar e comparar a comunidade de macroinvertebrados de duas espécies de bromélias de fragmentos de Mata Atlântica. Uma é característica de Floresta Ombrófila Densa, Aechmea ornata, e a outra ocorre 
em Floresta Ombrófila Mista, Aechmea recurvata. Amostramos e identificamos macroinvertebrados de 24 bromélias, 12 de cada espécie. No total foram registrados 19 táxons e 656 espécimes. No geral, Diptera foi a ordem de inseto mais abundante $(\mathrm{n}=417)$, representada principalmente por culicídeos $(\mathrm{n}=227)$ e quironomídeos $(\mathrm{n}=107)$, seguidos por besouros Scirtidae $(\mathrm{n}=216)$. Comparativamente a $A$. recurvata, $A$. ornata apresentou maior abundância e menor riqueza de invertebrados. Sete táxons foram exclusivos de $A$. recurvata, oito foram comuns a ambas e quatro, incluindo uma esponja, ocorreram apenas em $A$. ornata. Até onde sabemos, este é o primeiro registro de esponjas em bromélias. Observamos que os táxons de invertebrados mais abundantes eram comuns a ambas as bromélias e são considerados típicos de ambientes lênticos. Por outro lado, o elevado número de táxons exclusivos indica que os esforços de conservação devem incluir bromélias dessas duas fitofisionomias para garantir a diversidade das comunidades de fitotelmatas.

Palavras-chave: fitotelmata; insetos aquáticos; Floresta Ombrófila; diversidade.

The Atlantic Rainforest is a biodiversity hotspot that harbors several endemic species (Myers et al., 2000; Fundação SOS Mata Atlântica, 2017). For instance, of the 803 species of bromeliads that occur in the Atlantic Forest, 653 are endemic from this biome (Martinelli et al., 2008). The bromeliads are rosette-forming plants classified as phytotelmata (see Freitas et al., 2016 for examples). The typical bromeliad morphological structure originates from the overlapping of leaves and formation of a tank that accumulates water (i.e., the phytotelma) and decomposing organic matter. This creates an ecologically important microcosm for diverse animal communities, which use the bromeliads as a site for foraging, refuge, and reproduction (Richardson, 1999; Sodré et al., 2010). Aquatic invertebrates such as annelids, flatworms, gastropods, bivalves, crustaceans, mites, and mostly insects comprise the major animal groups that occupy bromeliad habitats (Hauer and Resh, 1996). In this study, we aimed to characterize the macroinvertebrate community of two bromeliad species from distinct Atlantic Forest phytophysiognomies. The two species, Aechmea ornata and Aechmea recurvata, are botanically known and well-studied, though we did not find studies that investigated the associated macroinvertebrate fauna.

We sampled aquatic macroinvertebrates in November/2015, September/2016, and December/2016 from 24 bromeliads by aspiration of the tank water, according to the methodology described by Sodré et al. (2010), selected to prevent plant damage. Twelve of these were the rupicolous bromeliad Aechmea ornata, which is a common endemic species in the Dense Ombrophilous Forest (DOF) (Martinelli et al., 2008), sampled at the Ilha do Mel, Paranaguá, Paraná (2533'44” S; 4819'07" W) within an area of approximately $40 \mathrm{~m}^{2}$ (with an average distance of $2 \mathrm{~m}$ among individuals). The other 12 were the epiphytic Aechmea recurvata, a common and widespread species in the Mixed
Ombrophilous Forest (MOF), sampled at the Parque Municipal das Araucárias, Guarapuava, Paraná $\left(25^{\circ} 21^{\prime} 35^{\prime \prime}\right.$ S; 51 $\left.28^{\prime} 16^{\prime \prime} \mathrm{W}\right)$, within an area of approximately $30 \mathrm{~m}^{2}$ (with an average distance of $3 \mathrm{~m}$ among individuals). The two sampling sites are preserved areas within Conservation Units, though the surroundings of the Parque Municipal das Araucárias are under stronger anthropic pressure. The $A$. ornata bromeliads were in more opened canopy sites; their tanks held on average $142 \mathrm{ml}$ of water $( \pm 104.8)$, with an average $\mathrm{pH}$ of $6.2( \pm 1.2)$ and $8.5 \mathrm{mg} . \mathrm{L}^{-1}( \pm 0.7)$ of dissolved oxygen. Aechmea recurvata were in closed canopy and held $55 \mathrm{ml}( \pm$ 12.2) of water on average, with an average $\mathrm{pH}$ of $4.5( \pm 0)$ and $5.5 \mathrm{mg} . \mathrm{L}^{-1}( \pm 3.5)$ of dissolved oxygen.

The sampled macroinvertebrates were fixed in $10 \%$ formalin solution, sorted, identified, and preserved in ethanol $70 \%$. To characterize bromeliad communities, we calculated macroinvertebrate relative abundance and manually built a descriptive network with species occurrence in each bromeliad species. We also did a similarity analysis (ANOSIM) in the Primer v6 software (Clarke \& Gorley, 2006), with $\log (\mathrm{X}+1)$-transformed abundance data and the Bray-Curtis similarity coefficient, to check whether invertebrate communities differed between bromeliads.

A total of 656 specimens of 19 taxa were sampled, being 12 taxa and 413 specimens sampled in A. ornata and 15 taxa and 243 specimens in $A$. recurvata (Table 1). Seven taxa were exclusive of $A$. recurvata, eight were common to both, and four, including a sponge, occurred only in $A$. ornata (Figure 1). Overall, the macroinvertebrate samples from $A$. ornata and $A$. recurvata were separated, though with a large overlap (ANOSIM: $\mathrm{R}=0.337$; $P=0.001$ ).

The epiphytic habit of $A$. recurvata bromeliads in the MOF, a site with dense canopy cover and high precipitation, probably contributed to the large accumulation of leaf litter and organic matter 
Table 1. List of taxa, name abbreviations (used in Figure 1), abundance, functional feeding groups and richness of macroinvertebrates sampled in Aechmea ornata and Aechmea recurvata bromeliads from Dense Ombrophilous Forest and Mixed Ombrophilous Forest fragments, respectively, Paraná state, Brazil.

\begin{tabular}{|c|c|c|c|c|}
\hline \multirow[b]{2}{*}{ Animal taxa } & \multirow[b]{2}{*}{ Abbreviation } & \multicolumn{2}{|c|}{ Bromeliad species } & \multirow[b]{2}{*}{ Functional feeding group } \\
\hline & & $\begin{array}{c}\text { Aechmea } \\
\text { ornata }\end{array}$ & $\begin{array}{l}\text { Aechmea } \\
\text { recurvata }\end{array}$ & \\
\hline Porifera & Porif & 1 & 0 & Filterer \\
\hline \multicolumn{5}{|l|}{ Naididae } \\
\hline Pristina & Prist & 0 & 13 & Collector gatherer \\
\hline Araneae & Aran & 2 & 0 & Predator \\
\hline Hydracarina & Hydr & 0 & 1 & Predator \\
\hline Collembola & Coll & 0 & 1 & Collector gatherer \\
\hline Formicidae & Form & 1 & 3 & Shredder \\
\hline Culicidae & Cul & 145 & 82 & Collector gatherer \\
\hline Ceratopogonidae (adult/pupae) & Cerato & 2 & 11 & Collector gatherer; predator \\
\hline Atrichopogon & Atric & 0 & 6 & Collector gatherer \\
\hline Bezzia & Bezz & 0 & 6 & Predator \\
\hline Ceratopogonidae morphotype $I^{*}$ & D_morph & 34 & 23 & - \\
\hline \multicolumn{5}{|l|}{ Chironomidae } \\
\hline Ablabesmyia & Ablab & 8 & 0 & Predator \\
\hline Limnophyes & Limno & 14 & 66 & Collector gatherer \\
\hline Polypedilum & Polyp & 13 & 0 & Shredder; collector gatherer \\
\hline Empididae & Empid & 2 & 1 & Predator \\
\hline Psychodidae & Psychod & 1 & 1 & Collector gatherer, scraper \\
\hline Tipulidae & Tipul & 0 & 2 & Predator \\
\hline Noteridae & Noter & 0 & 1 & Predator \\
\hline Scirtidae & Scirt & 190 & 26 & Scraper \\
\hline Total abundance & - & 413 & 243 & \\
\hline Total taxa richness & _ & 12 & 15 & \\
\hline
\end{tabular}

${ }^{*}$ Ceratopogonidae morphotype I - unidentified Ceratopogonidae genus (D_morph = Diptera morphotype).

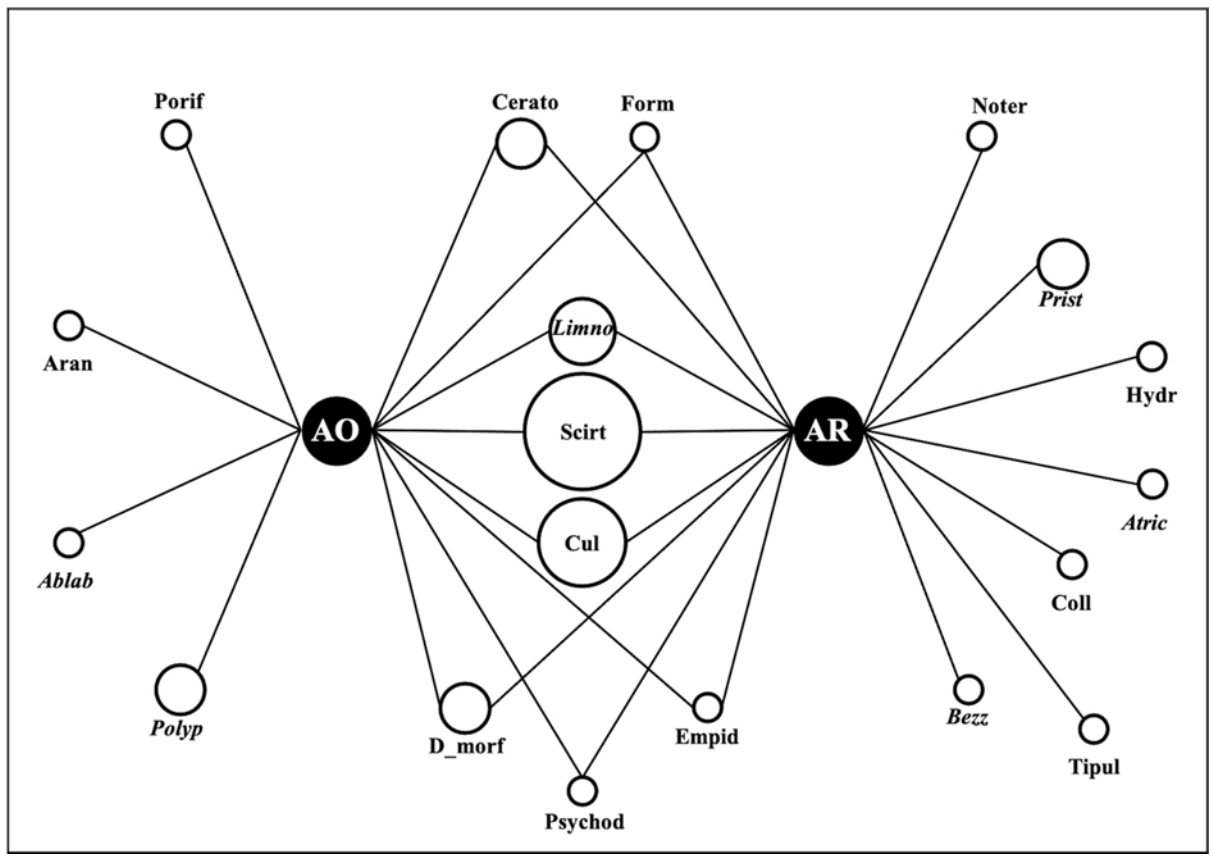

Figure 1. Network representing the occurrence (lines) of macroinvertebrate taxa (white circles) in the bromeliads Aechmea ornata (AO) and Aechmea recurvata (AR) (black circles) in Atlantic Rainforest fragment of the Paraná state. The circle size is proportional to species abundance categories (intervals of 50 specimens), with smallest circles representing taxa with up to ten specimens and largest circles representing taxa with 150-200 specimens. Taxa abbreviations are listed in Table 1. 
in their tanks. This finding may be related to the exclusive presence of Pristina (Naididae) earthworms in these bromeliads, since they feed on plant detritus and play an important role in organic matter processing (Gorni \& Alves, 2015). On the other hand, the rupicolous habit of $A$. ornata bromeliads, present in more opened areas of DOF near the beach, probably contributed to clearer water and lower organic matter concentration (pers. obs.). This finding may in turn be related to the exclusive presence of sponges in these bromeliads. Sponges can inhabit several freshwater environments, both permanent and temporary, being more frequent in clear waters, free from contaminants (Mugnai et al., 2010), and in silicate-rich waters due to their skeleton constitution (Volkmer-Ribeiro \& Parolin, 2010). There are numerous records of sponges in Atlantic Forest streams, such as Oncosclera jewelli (Volkmer, 1963), registered in streams of the Planalto das Araucárias and Campos de Altitude regions (Maciel et al., 2001), though their presence in bromeliad plants is quite uncommon - to our knowledge, this is the first record. However, it was one single record and since it was not possible to identify the sponge, it is possible that this occurrence may have been accidental. Thus, further studies are needed to investigate sponge occurrence in tank plants and their relationships with other bromeliad animals.

The most abundant insect order was Diptera, especially the mosquito larvae (Culicidae, the most abundant family) and non-biting midges, followed by Coleoptera, represented mostly by scirtid beetles. Mosquito larvae are cosmopolitan and quite common in lentic waters, occupying from large lakes to rainfall ponds and phytotelmata. They play an important role in bromeliad food webs and can occupy different trophic levels, form primary consumers, as microbial filter-feeders, to top predators (Kitching, 2001). Representatives of many mosquito genera, such as Aedes, reproduce almost exclusively in phytotelmata (Kitching, 2001). Similarly, many beetles of the Scirtidae family, which also presented a high abundance in our study, are also closely associated with phytotelmata (Mestre et al., 2001). They are detritivorous species (i.e., feed on dead organic matter) that break-up large detritus into finer particles, making them available for other animals; they can even act as facilitators to other species, such as midges (Kitching, 2001). Conversely, non-biting midges of the Chironomidae family are associated not only to lentic habitats, being widespread, rich, and abundant in virtually all other freshwater environments - and some salty ones as well (Ferrington-Junior, 2008). They were the third most abundant family in this study. Limnophyes chironomid midges had already been sampled in Atlantic Forest and mountain streams, though they are rarely found in bromeliads (Trivinho-Strixino, 2011); Polypedilum, however, are known to occur in both epiphytic and rupicolous tank plants (Saether et al., 2010). Collector-gatherers, which feed on fine particulate organic matter deposited on the submerged substrate, and scrapers, which scrape periphyton from the surface of the leaves (Berg, 1995), were the predominant functional feeding groups in both bromeliads.

The phytotelmata present in $A$. ornata and $A$. recurvata harbored an aquatic invertebrate richness comparable to another Aechmea species (Aechmea distichantha Lem.), which found 16 morphospecies of four insect orders (Amadeo et al., 2017). There are several factors that can influence the diversity of bromeliad invertebrate communities, from fluctuations of tank water volume and limnological parameters (Neves et al., 2019) to flowering events (Amadeo et al., 2017). When it comes to rupicolous bromeliads near the sea, however, variations in salinity can also occur due to sea breeze. Although it was not possible to measure tank water salinity in our study, the lower taxa richness and higher abundance registered in A. ornata may have resulted from it. For instance, Polypedilum and Ablabesmyia are more commonly found in freshwaters, though they can tolerate some salinity (Williams et al., 1991), what may explain their occurrence in $A$. ornata.

In summary, the most abundant macroinvertebrate taxa were common to both bromeliad species and are regarded as typical of lentic environments. Notwithstanding, over half of the sampled taxa were exclusive, being $21 \%$ exclusive of $A$. ornata and $37 \%$ exclusive of $A$. recurvata.

Thus, our results indicate that conservation efforts should include bromeliads from these two phytophysiognomies to ensure the diversity of phytotelmata communities in the Atlantic Rainforest. Further studies that add up to a broader sampling effort to inventory macroinvertebrates of bromeliad phytotelmata in the Atlantic Forest would be welcome and could include the investigation of the occurrence of sponges in these tank plants. 


\section{Acknowledgements}

We are thankful to Dr. Rosângela C. Tardivo from the Universidade Estadual de Ponta Grossa and to Dr. Adriano Silvério from the Universidade Estadual do Centro-Oeste for the identification of the two bromeliad species.

\section{References}

AMADEO, F.E., DIAS, J.D., SEGOVIA, B.T., SIMÓES, N.R. and LANSAC-TÔHA, F.A. Effects of bromeliad flowering event on the community structuring of aquatic insect larvae associated with phytotelmata of Aechmea distichantha Lem. (Bromeliaceae). Acta Limnologica Brasiliensia, 2017, 29, e111. http://dx.doi. org/10.1590/s2179-975x3417.

BERG, M.B. Larval food and feeding behavior. In: P.D. ARMITAGE, P.S. CRANSTON and L.C.V. PINDER, eds. The Chironomidae: biology and ecology of non-biting midges. London: Chapman \& Hall, 1995, p. 136-168.

CLARKE, K.R. and GORLEY, R.N. PRIMER-e. Plymouth: PRIMER, 2006.

FERRINGTON-JUNIOR, L.C. Global diversity of non-biting midges (Chironomidae; Insecta-Diptera) in freshwater. Hydrobiologia, 2008, 595(1), 447-455. http://dx.doi.org/10.1007/s10750-007-9130-1.

FREITAS, L., SALINO, A., MENINI NETO, L., ALMEIDA, T.E., MORTARA, S.R., STEHMANN, J.R., AMORIM, A.M., GUIMARÁES, E.F., COELHO, M.N., ZANIN, A. and FORZZA, R.C. A comprehensive checklist of vascular epiphytes of the Atlantic Forest reveals outstanding endemic rates. PhytoKeys, 2016, 58(58), 65-79. http://dx.doi. org/10.3897/phytokeys.58.5643. PMid:26884706.

FUNDAÇÃO SOS MATA ATLÂNTICA. Instituto Nacional de Pesquisas Espaciais - INPE. Atlas dos remanescentes florestais da mata atlântica periodo 2015 2016. Relatório técnico. São Paulo, 2017.

GORNI, G.R. and ALVES, R.G. Influência de variáveis ambientais sobre a comunidade de oligoquetos (Annelida: Clitellata) em um córrego neotropical. Revista Biotemas, 2015, 28(1), 59-66. http://dx.doi. org/10.5007/2175-7925.2015v28n1p59.

HAUER, F.R. and RESH, V.H. Benthic macroinvertebrates. In: F.R. HAUER and G.A. LAMBERTI, eds. Stream ecology. Academic Press, 1996, pp. 339-369.

KITCHING, R.L. Food webs in phytotelmata: "bottomup" and "top-down" explanations for community structure. Annual Review of Entomology, 2001, 46(1), 729-760. http://dx.doi.org/10.1146/annurev. ento.46.1.729. PMid:11112185.

MACIEL, F.O., ANDRADES-FILHO, C.O., HERRMANN, P.B. and REIS, M.S. COSTA, E.C. and PRINTES, R.C. Ambientes de ocorrência do porífero Oncosclera jewelli no Parque Estadual do Tainhas, Planalto Meridional do RS: uma análise geomorfométrica. Ciência e Natureza, 2001, 43, 1-27.

MARTINELLI, G., VIEIRA, C.M., GONZALEZ, M., LEITMAN, P., PIRATININGA, A., COSTA, A.F. and FORZZA, R.C. Bromeliaceae da Mata Atlântica brasileira: lista de espécies, distribuiçáo e conservação. Rodriguésia, 2008, 59(1), 209-258. http://dx.doi. org/10.1590/2175-7860200859114.

MESTRE, L.A.M., ARANHA, J.M.R. and ESPER, M.L.P. Macroinvertebrate fauna associated to the bromeliad Vriesea inflata of the Atlantic Forest (Paraná State, southern Brazil). Brazilian Archives of Biology and Technology, 2001, 44(1), 89-94. http:// dx.doi.org/10.1590/S1516-89132001000100012.

MUGNAI, R., NESSIMIAN, J.L. and BAPTISTA, D.F. Manual de identificação de macroinvertebrados aquáticos do estado do Rio de Janeiro. 1. ed. Rio de Janeiro: Technical Books, 2010.

MYERS, N., MITTERMEYER, R.A., FONSECA, G.A.B. and KENT, J. Biodiversity hotspots for conservation priorities. Nature, 2000, 403(6772), 853-858. http://dx.doi.org/10.1038/35002501. PMid:10706275.

NEVES, K.M.S., TAVARES, A.R., VERCELLINO, S. and FERRAGUT, C. Biomass and abiotic variables change in phytotelmic environment in the tankbromeliad Nidularium longiflorum Ule in tropical forest. Acta Limnologica Brasiliensia, 2019, 31, e24. http://dx.doi.org/10.1590/s2179-975x4217.

RICHARDSON, B.A. The bromeliad microcosm and the assessment of faunal diversity in a Neotropical Forest. Biotropica, 1999, 31(2), 321-336. http:// dx.doi.org/10.1111/j.1744-7429.1999.tb00144.x.

SAETHER, O.A., ANDERSEN, T., PINHO, L.C. and MENDES, H.F. The problems with Polypedilum Kieffer (Diptera: Chironomidae), with the description of Probolum subgen. Zootaxa, 2010, 2497(1), 1-36. http://dx.doi.org/10.11646/zootaxa.2497.1.1.

SODRÉ, V.M., ROCHA, O. and MESSIAS, M.C. Chironomid larvae inhabiting bromeliad phytotelmata in a fragment of the Atlantic Rainforest in Rio de Janeiro State. Brazilian Journal of Biology = Revista Brasileira de Biologia, 2010, 70(3), 587-592. http://dx.doi.org/10.1590/S151969842010000300015. PMid:20730345.

TRIVINHO-STRIXINO, S. Larvas de Chironomidae: guia de identificação. São Carlos: Laboratório de Entomologia Aquática, Universidade Federal de São Carlos, 2011.

VOLKMER-RIBEIRO, C. and PAROLIN, M. As esponjas. In: M. PAROLIN, C. VOLKMERRIBEIRO and J.A. LEANDRINI, eds. Abordagem ambiental interdisciplinar em bacias hidrográficas no Estado do Paraná. Campo Mourão: Editora da Fecilcam, 2010, pp. 105-130. 
WILLIAMS, W.D., TAAFFE, R.G. and BOULTON,

Received: 10 May 2021

A.J. Longitudinal distribution of macroinvertebrates Accepted: 14 September 2021 in two rivers subject to salinization. Hydrobiologia, 1991, 210(1), 151-160. http://dx.doi.org/10.1007/ BF00014329.

Associate Editor: Victor Satoru Saito. 